\title{
Cytomorphological and autoradiografical studies on the receptacle of the strawberry (Fragaria grandiflora Eherh.) in the initial stages of development
}

\author{
JAN SZYMAŃSKI \\ Institute of Vegetable Crops ul. 22 Lipca 1/3, 96-100 Skierniewice, Poland
}

(Received: July 8, 1986)

A bstract

\begin{abstract}
The volume of the cortex and pith cells of strawberries from the cultivar Talizman gradually increased until ripening, especially in the cortex. The volume of the nucleus also increased. The nuclei in the pith were smaller then in the cortex. The volume of the nucleolus increased significantly between days 1 and 5 after pollination, after which it remained unchanged. At the end of the growth period, the volume of the nucleolus in cortical and pith cells in the lower and central part of the fruit increased. Endomitotic polyploidization which was responsible for the growth of the fruit, occurred during the development of the receptacle. The intensity of ${ }^{3} \mathrm{H}$ actinomycin binding reached a maximum in the oldest stages. This is proof for the accumulation of active DNA during mitosis. Saturation with this antibiotic occurred in the early stages of fruit development. No dependence between the volume of cells and the number of nuclei binding ${ }^{3} \mathrm{H}$ actinomycin was observed.
\end{abstract}

\section{INTRODUCTION}

Studies on the changes in the size and number of cells in the early stages of development of the strawberry receptacle ( $\mathrm{S} \mathrm{z} \mathrm{y} \mathrm{m} \mathrm{a} \mathrm{ń} \mathrm{s} \mathrm{k} \mathrm{i,} \mathrm{1982)} \mathrm{showed} \mathrm{that} \mathrm{the}$ receptacle's cortex is mainly responsible for its growth. It enlarges in the various parts of the receptacle due to:

a) cellular divisions, by which the number of cells constantly increases. This increase equals $56 \%$ in the middle part and $49 \%$ in the apical part during the period from days 1 to 10 after pollination (a.p.), that is, until the start of ripening, 
b) increase in cell size which occurs all throughout the studied period of 1-20 days a.p. (except that between 5-20 growth occurs gradually while between days $1-5$ very intensely).

The development of the pith does not affect the growth of the receptacle very much and the number of its cells increases by $7 \%$ in the middle level to $22 \%$ in the lower level. The cell divisions there occur practically only during days 1-5 a.p. The increase in pith cell volume, however, takes place constantly in the studied developmental stages. The increase in cell size is manifested, among others, in the increase in tisuue hydration.

The relationship between cell size and fruit size is well known ( $\mathrm{H} \mathrm{o} \mathrm{u} \mathrm{g} \mathrm{h} \mathrm{t} \mathrm{a}$ $1 \mathrm{ing}$, 1935; M a c Arthur and We tmore, 1941; S i n not t, 1939; Tu ke $y$ and Y o u ng, 1942). Whereas there are few studies on the changes in DNA content during fruit development (P e a r s o n et al., 1974; $\mathrm{N} \mathrm{a} \mathrm{g} \mathrm{1,} \mathrm{1978).}$

The objective of this study was to examine the relationship between the increase in cell size and the changes in nucleus and nucleolus volumes in succesive periods of strawberry receptacle development. Endoreplication of nuclear DNA and changes in the availability of DNA during transcription were also taken into account.

\section{MATERIALS AND METHODS}

The study was conducted on strawberry fruit of the variety Talizman (Fragaria grandiflora Ehrh. cv. Talisman). Only the fruits from the main stem of the inflorescence were examined because of the well known differences in the chemical composition between fruits formed at different periods ( $\mathrm{G} \mathrm{r}$ a i $\mathrm{n} \mathrm{g} \mathrm{e} \mathrm{r,} \mathrm{1956).}$ Fruits chosen with a $95 \%$ degree of tolerance in respect to height and diameter were used in the study. The cytomorphological examinations were done on fruit taken 1, 5, 10 and 20 days a.p. and prepared in the following way: the fruits were cut into three parts, lower (A), middle (B) and apical (C) (Fig. 1).

The material was fixed in a formalin acetic alkohol fixative - FAA (J e $\mathrm{n}$ s e n, 1962) and ambedded in a mixture of paraffin with wax or paraffin with gum (S z y m a ń s k i, 1982), affter which it was stained with safranine and strong green. Transverse and longitudinal sections of the three parts (levels) of the fruit $(a, b, c)$ were made taking into account the studied developmental stages.

The volumes of cells, nuclei and nucleoli were calculated on the basis of the diameters of these objects on the transverse and longitudinal sections. 


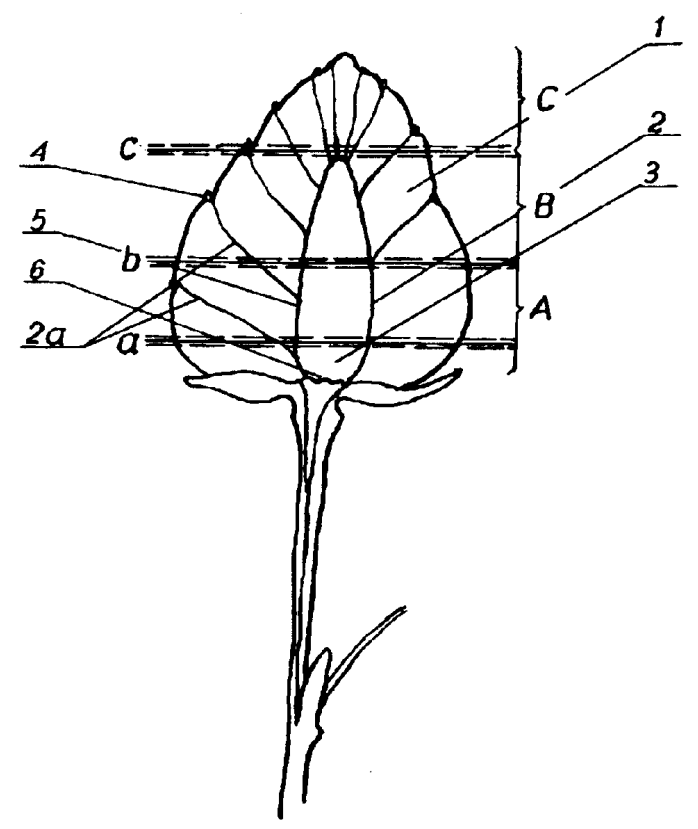

Fig. 1. A longitudinal section throught a strawberry receptacle

1 - cortex, 2 and 5 - vascular bundles separating the cortex and pith, $2 a$-vascular bundles in the cortex, 3 - pith, 4 - achene, 6 -base of the receptacle $a, b, c$ - the levels on which the receptacle was cut, from which the largest cross and longitudinal sections were made. A - the lower part from the base of the receptacle to level b, B - the middle part from level b to level c, C - the apical part from level $c$ to the apex of the fruit

The size of the studied cells is close to a flattened rotational ellipsoid, therefore the following formula may be applied:

$$
\mathrm{V}=1 / 6 \times \mathrm{xy}^{2}
$$

where: $x$ - the short axis on the transverse section

$y$ - the long axis on the cross section

The volume of the nuclei was also calculated as that of an ellipsoid because of the similarity of nuclei to this geometric solid. It was noticed that the nuclei were not as similar to this soild as the cells, that is why two axes on the cross-section were taken into account. The following formula was applied:

$$
\mathrm{V}=1 / 6 \times \mathrm{x}_{1} \mathrm{x}_{2} \mathrm{y}^{2}
$$

where: $x_{1}$ - the short axis on the cross-section

$\mathrm{x}_{2}$ - the median axis on the cross-section

$y$ - the long axis on the longitudinal section

The volume of nucleoli, which are similar to spheres, was calculated using the following formula:

$$
\mathrm{V}=1 / 6 \quad \mathrm{x} \mathrm{x}^{3}
$$

where: $\quad x$ - the diameter of the nucleolus 
In order to study the synthesis of DN, ${ }^{3} \mathrm{H}$-thymidine $3,7 \mathrm{MB} \mathrm{q} / \mathrm{ml}$, with a specific activity of $185 \mathrm{~GB} \mathrm{q} / \mathrm{mmol} / 10 \mu \mathrm{C} / \mathrm{ml}$ was used. From the two tried methods of introducing ${ }^{3} \mathrm{H}$ thymidine into the receptacle, the so-called floating of the studied fruit parts, the same as used in the anatomical and biometrical studies (A, B, C), was used. Incubation was conducted for $24 \mathrm{hrs}$. Depending on the developmental stage and fruit parts, various amounts of liquid per fruit part were used: 1 day after pollination $-2 \mathrm{ml}$

5 days after pollination $-4 \mathrm{ml}$

10 days after pollination $-6 \mathrm{ml}$

20 days after pollination $-10 \mathrm{ml}$

After incubation the material was fixed in FAA after which paraffin sections were made according to the method described above. The slides were covered with Ilford $\mathrm{G} 5$ emulsion and after 2 weeks of exposition, the autoradiographs were developed, fixed and stained with Unna's reagent and sealed in Canadian balsam.

Changes in the availability of DNA were examined with the aid of ${ }^{3} \mathrm{H}$ actinomycin $\mathrm{D}, 3,7 \mathrm{MB} \mathrm{q} / \mathrm{ml}$ with a specific activity of $324,8 \mathrm{BG} \mathrm{q} / \mathrm{mmol} / 10 \mu \mathrm{C} / \mathrm{ml}$. The material, fixed in FAA and in the form of paraffin sections, was incubated with this antibiotic for $1 \mathrm{hr}$ according to the method proposed by $\mathrm{B}$ e r l o w i t $\mathrm{z}$ et al. (1969) and then applied to plan material by K o n o n o w i c z et al. (1976) and O 1 s z e w s k a (1976). The slides were covered with Ilford G 5 emulsion, exposed for 14 days, developed and fixed, then stained using the Unna method.

The fresh and dry weights of fruit were measured using 30 strawberry fruits. The fresh weight was determined first, then compared with the dry weight.

Dry weight was determined as follows: the studied parts were placed in a thermostat heated to a temperature of $105^{\circ} \mathrm{C}$ and kept there for $20 \mathrm{~min}$., and then dried to a constant weight for $3 \mathrm{hrs}$. at $70^{\circ} \mathrm{C}$ ( $\mathrm{B} \mathrm{i} 1 \mathrm{e} \mathrm{c} \mathrm{k} \mathrm{a}, 1974$ ).

The results of the measurements of the volumes of cells, nuclei and nucleoli were subjected to statistical analysis by variance analysis and the significance of the differences between mean values were evaluated using Student's test at the $5 \%$ level. The values of the limit differences are denoted by the symbol LSD (least significant difference).

\section{RESULTS}

The volume of the cells is presented on Fig. 2. In all of the studied levels $(a, b)$ and in all of the developmental stages except 1 day a.p. in the lower part and 
5 days a.p. in the middle part (b), the cortex cells were larger than the pith cells (with the exception of 1 day a.p. in the lower part (a) and 5 days a.p. in the middle part (b)). The volume of the cells 10 days a.p. in the lower part and middle part was almost equal, whereas in the apical part it was smaller. Its value remained here similar to that in the middle and apical part at the stage 5 days a.p.. In the stages 5, 10 and 20 days after a.p. in level (b), a distinct difference in the growth of cortex cells in respect to pith cells was visible. The cortex cells were larger than the pith cells with the exception of 1 day a.p. in the lower, (a) part and 5 days a.p. in the middle part.

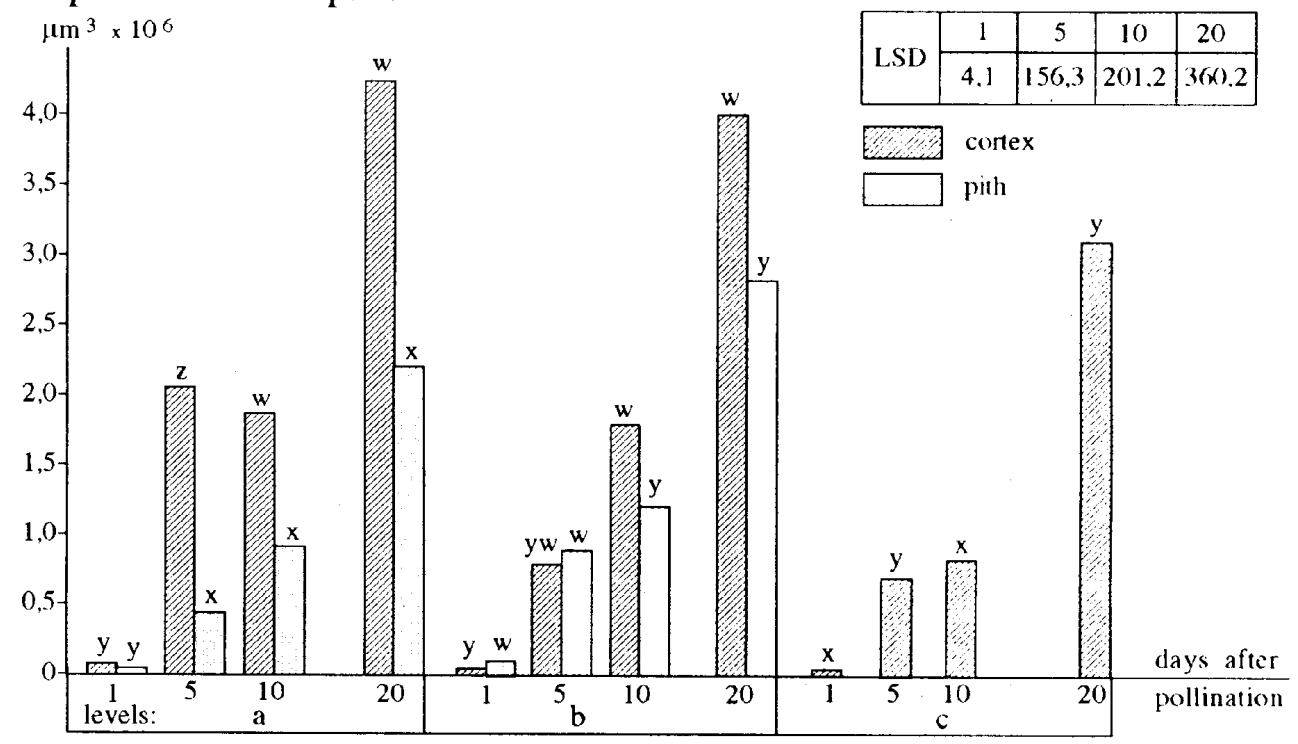

Fig. 2. Changes in the volume of the contex and pith cells of the strawberry receptacle

Within each of the particular stages (1,5, 10,20 days a.p.) the columns denoted by the same lelters do not differ from each outer significanlly. (We therefore compare e.g. colurnis 1 from the levels a,b,c, columns 5 from the levels a, b, c, etc.), a, b.c - levels of sectioning the receptacle in accirdance with Fig. 1 , from which cross and transverse sections were made and on which the diameters used to calculate volumes were measured

The lergest increase in cortex cell volume was observed in the lower part (a) between days 1 and 5 a.p. and in the apical part between days 10 and 20 a.p. The volume of the cortex in the middle part, however, increased gradually.

As the volume of the cortex and pith cells increased, so did the volume of the nuclei (Fig. 3). In the youngest stages ( 1 and 5 days a.p.) in all of the studied parts, the volume of the cortex cells was equal. The volumes of the pith nuclei were at that moment a bit larger. In the older stages ( 10 and 20 days) the volume of the nuclei in the cortex distinctly increased. In the pith in the 10 day stage in part (a), the volume of the nuclei increased, while in the next stage, it dropped by almost one-half. In the middle part the volume of the nuclei 10 and 20 days a.p. was almost equal. 


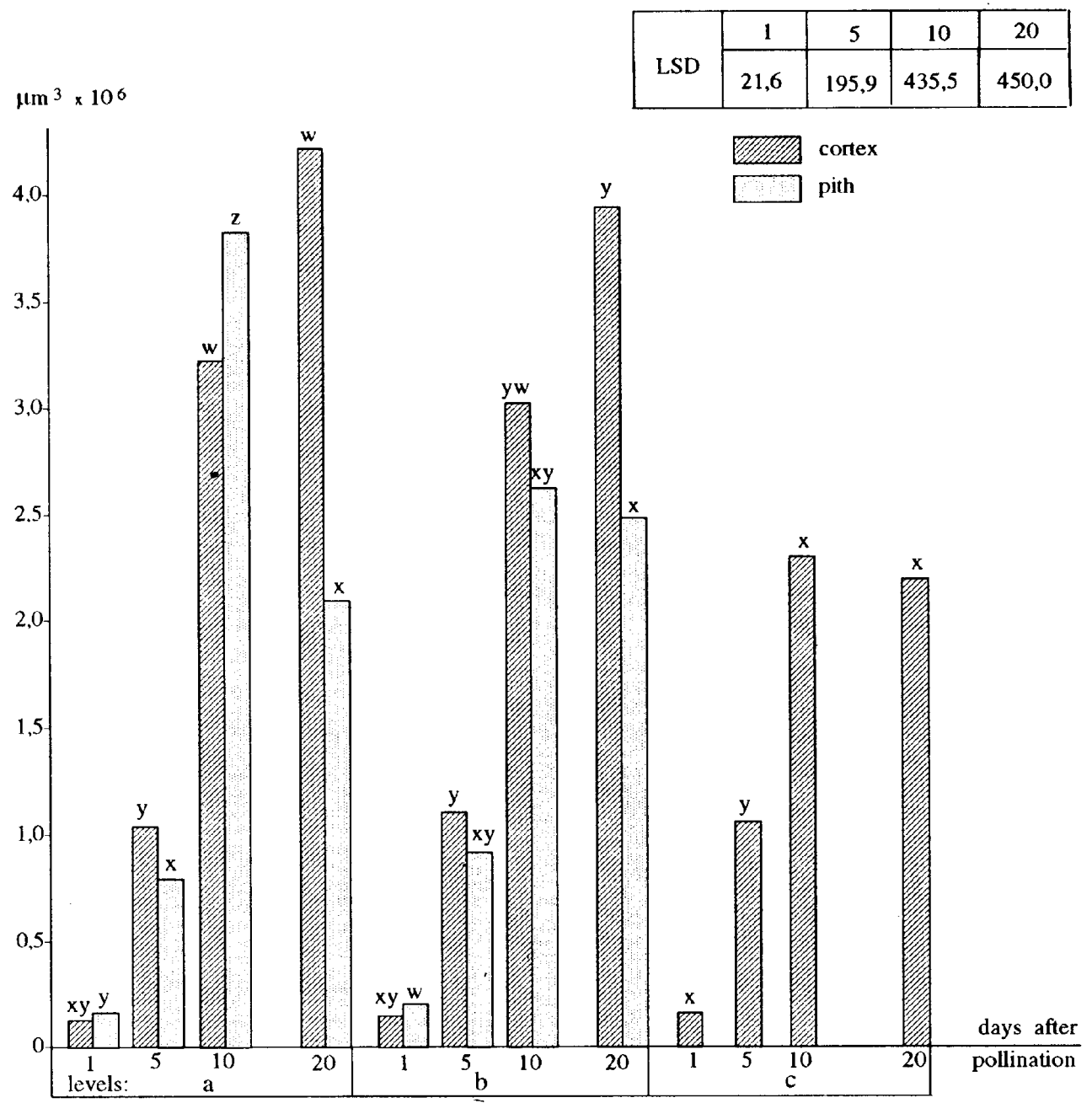

Fig. 3. Changes in the volume of cortex and pith nuclei of the strawberry receptale

a, b, c-levels of sectioning the receptacle in accordance with Fig. 1, from which cross and transverse sections were made and on which the diameters used to calculate volumes were measured.

Other details as in Fïg. 2

The volume of the nucleoli was measured in the cortex and pith and the results are presented jointly for both of these fruit parts because thay were the same (Fig. 4). The smallest nucleoli were found 1 day a.p.. In the 5 and 10 days a.p. stages their dimensions were similar and increased until the 20 day stage, but only in the lower and middle parts. 


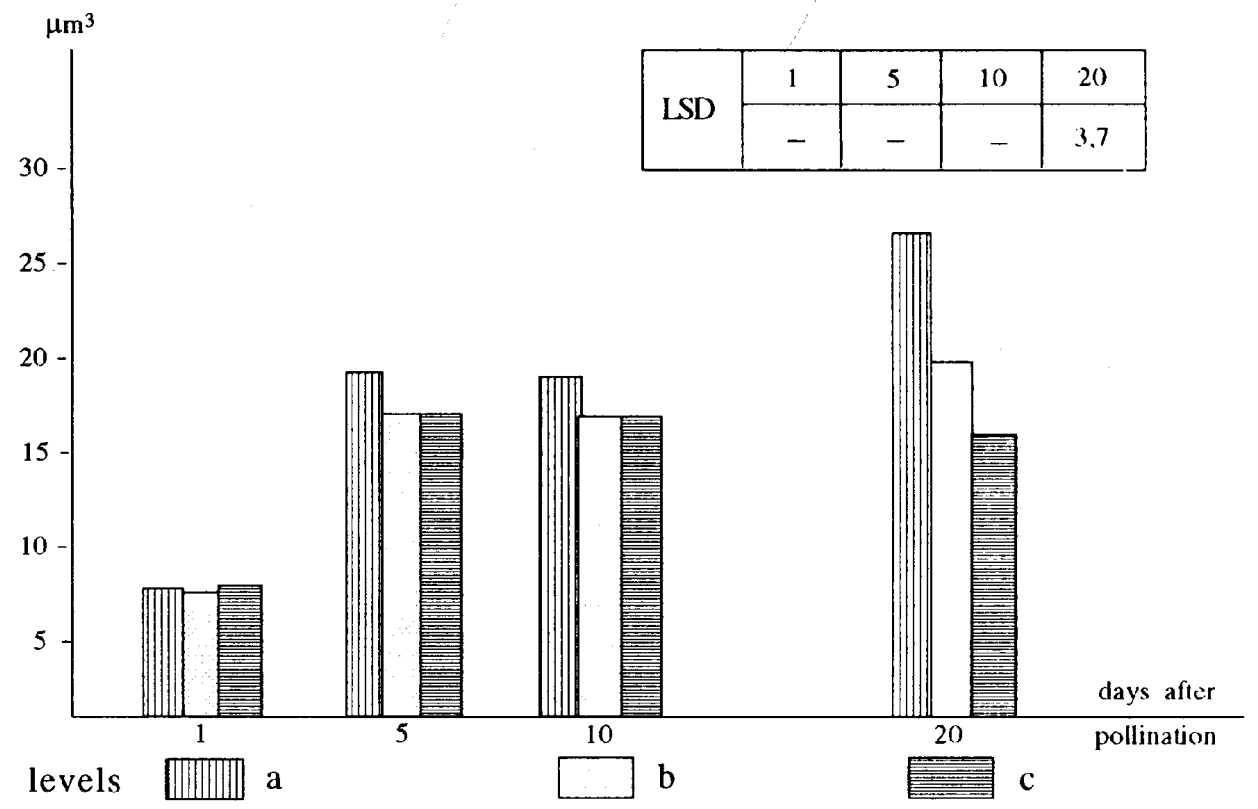

Fig. 4. Changes in the volume of the nucleolus in the cortex and pith of the stawberry receptacle (with the different sites of sectioning the fruit taken into account)

a, b. c - the denotations used for the succesive levels of sectioning marked in Fig. 1 for day 1 a. p. apply 10 all developinental stages 1 .SD was marked only for the 20 days a. p. stage because for all the other it equalied 0 . Other details as in Fig. 2

A distinct change in the volume of the nucleoli was seen between the 1 and 5 day stages. The reported values were calculated on the basis of diameters which ranged from 2,5 to $3,7 \mu \mathrm{m}$. Somewhat more than 10 nuclei were found to contain 2-3 nucleoli, especially in the cortex. In such cases, the volume of the nucleoli was calculated jointly.

Ta ble 1

The fresh weight of strawberry fruit, in $\mathrm{mg}$

\begin{tabular}{|c|c|c|c|c|}
\hline \multirow{2}{*}{$\begin{array}{c}\text { Receptacle } \\
\text { part }\end{array}$} & \multicolumn{4}{|c|}{ Development stage days after pollination } \\
\hline & 1 & 5 & 10 & 20 \\
\hline A & 42,89 & 80,12 & 234.92 & $216,3.54$ \\
\hline B & 37.00 & 46.79 & 189.13 & 1797.41 \\
\hline C & 27,03 & 37.16 & 93,08 & $9(6.72$ \\
\hline LSD & 3,908 & 2.938 & 42.969 & 214,672 \\
\hline
\end{tabular}


Table 2

The dry weight of stawberry fruit, in \%

\begin{tabular}{|c|cccc|}
\hline \multirow{2}{*}{$\begin{array}{c}\text { Receptacle } \\
\text { part }\end{array}$} & \multicolumn{4}{|c|}{ Development stage days after pollination } \\
\cline { 2 - 5 } & 1 & 5 & 10 & 20 \\
\hline A & 50,4 & 45,4 & 19,5 & 33,6 \\
B & 41,7 & 54,1 & 18,4 & 26,6 \\
C & 47,7 & 34,1 & 24,5 & 21.7 \\
\hline LSD & 9,00 & 8,71 & 4,15 & 8,17 \\
\hline
\end{tabular}

The fresh and dry weight of the examined fruits is presented in Tables 1 and 2 . The greatest increase in fresh weight was found in the period between 10 and 20 days a.p. in all of the parts of the receptacle.

The dry weight in all of the studied stages had the greatest absolute value in part A. However, the relative dry weight content, expressed as a percentage, was rather high in the 1 and 5 days a.p. stages, next it was much smaller in the 10 days a.p. stage. In the stage close to ripening, 20 days a.p., the dry weight content increased in parts $\mathrm{A}$ and $\mathrm{B}$, while only slightly dropping in part $\mathrm{C}$. At this stage the percentage of dry weight was the largest in the base of the receptacle and the lowest in its apical part.

The intensity of $3 \mathrm{H}$-thymidine incorporation ranged widely from only ten-odd grains per nucleus to almost complete coverage of the nuclei with dark grains of emulsion (Figs. 5-8). In the calculations, all of the labeled nuclei, regardless of the intensity, were treated as radioactive nuclei.

Fig. 9 presents the relationship between the call volumes and the number of ${ }^{3} \mathrm{H}$-thymidine-labeled nuclei. Aside from the nuclei in the middle and apical parts of the youngest stage, over $50 \%$ of the nuclei in all of the examined fruits were labeled in such a way that they could be said to be radioactive.

On day 1 a.p. the largest number of labeled nuclei was in part a, significantly less in part $b$, while none at all in part $c$. In the 20 days a.p. stage, when the volume of cells increases greatly, there was over $80 \%$ radioactive nuclei.

The largest nuclear volume corresponded with a high percentage of labeled nuclei. This was especially visible in the lower and middle parts. 

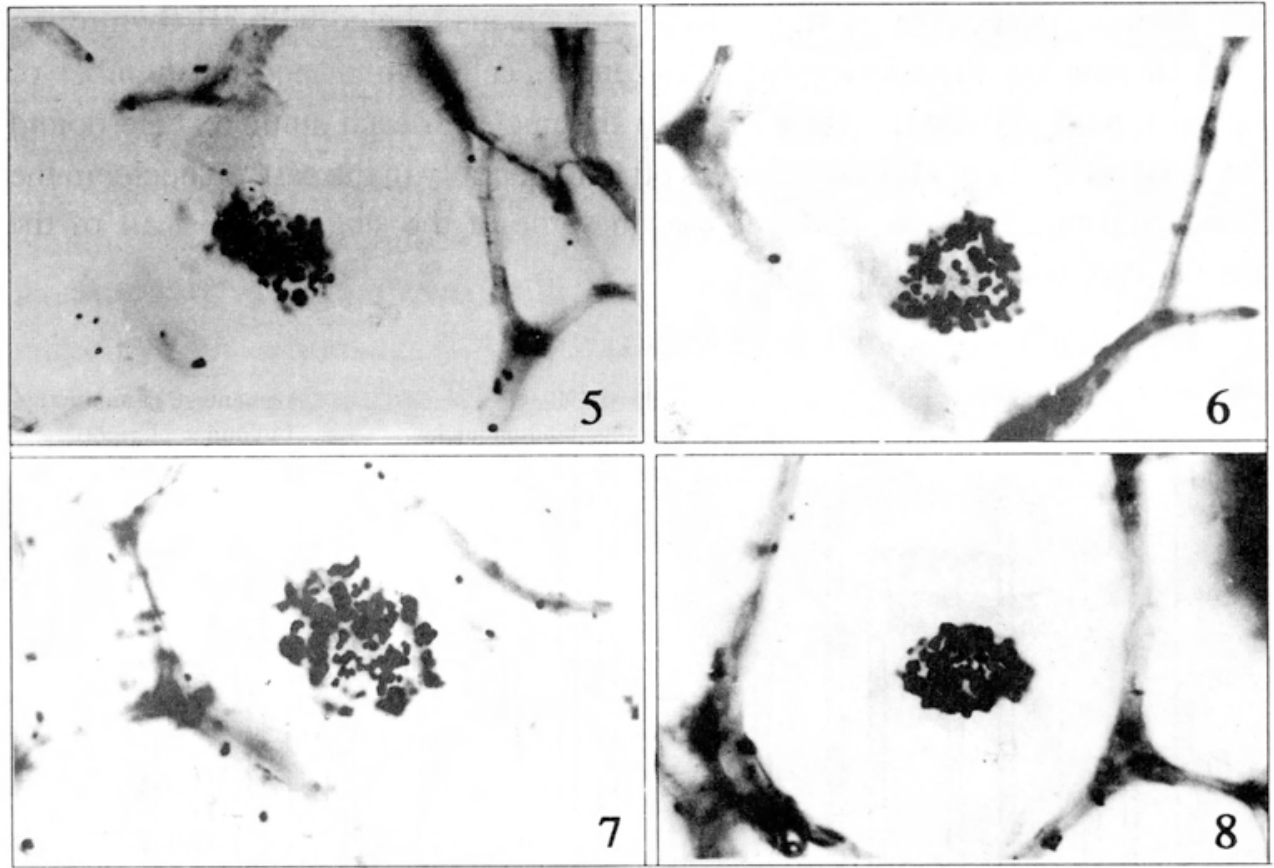

Figs. 5-8. Nuclei from the cortex of the receptacle 5 and 20 days a. p. (level a) Nuclei from autoradiograms with ${ }^{3} \mathrm{H}$-thymidine $\mathrm{x} 1200$

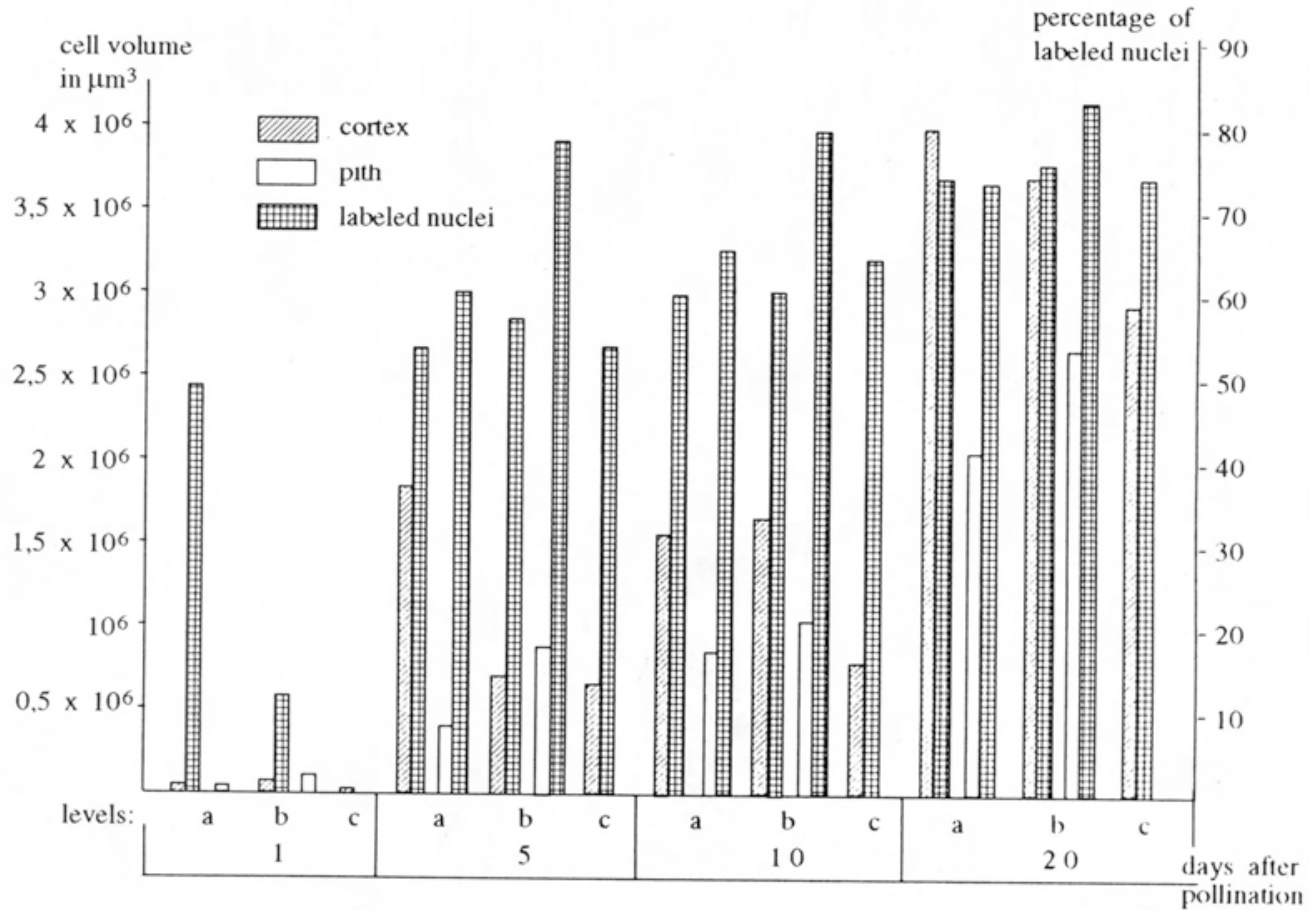

Fig. 9. The relationship between the cell volume and number of nuclei labeled with ${ }^{3} \mathrm{H}$-thymidine 
In none of the studied stages was the nucleous labeled with ${ }^{3} \mathrm{H}$-thymidine. Fig. 10 presents the relationship between the cell volume and the number of nuclei binding ${ }^{3} \mathrm{H}-\mathrm{AMD}$. Over $75 \%$ of the nuclei in each studied stage bound ${ }^{3} \mathrm{H}$-AMD (Fig. 11.). This binding was $60 \%$ lower only in the case on nuclei in the lower and middle parts of day 1 a.p. In some of the stages almost all of the nuclei were bound with ${ }^{3} \mathrm{H}-\mathrm{AMD}$.

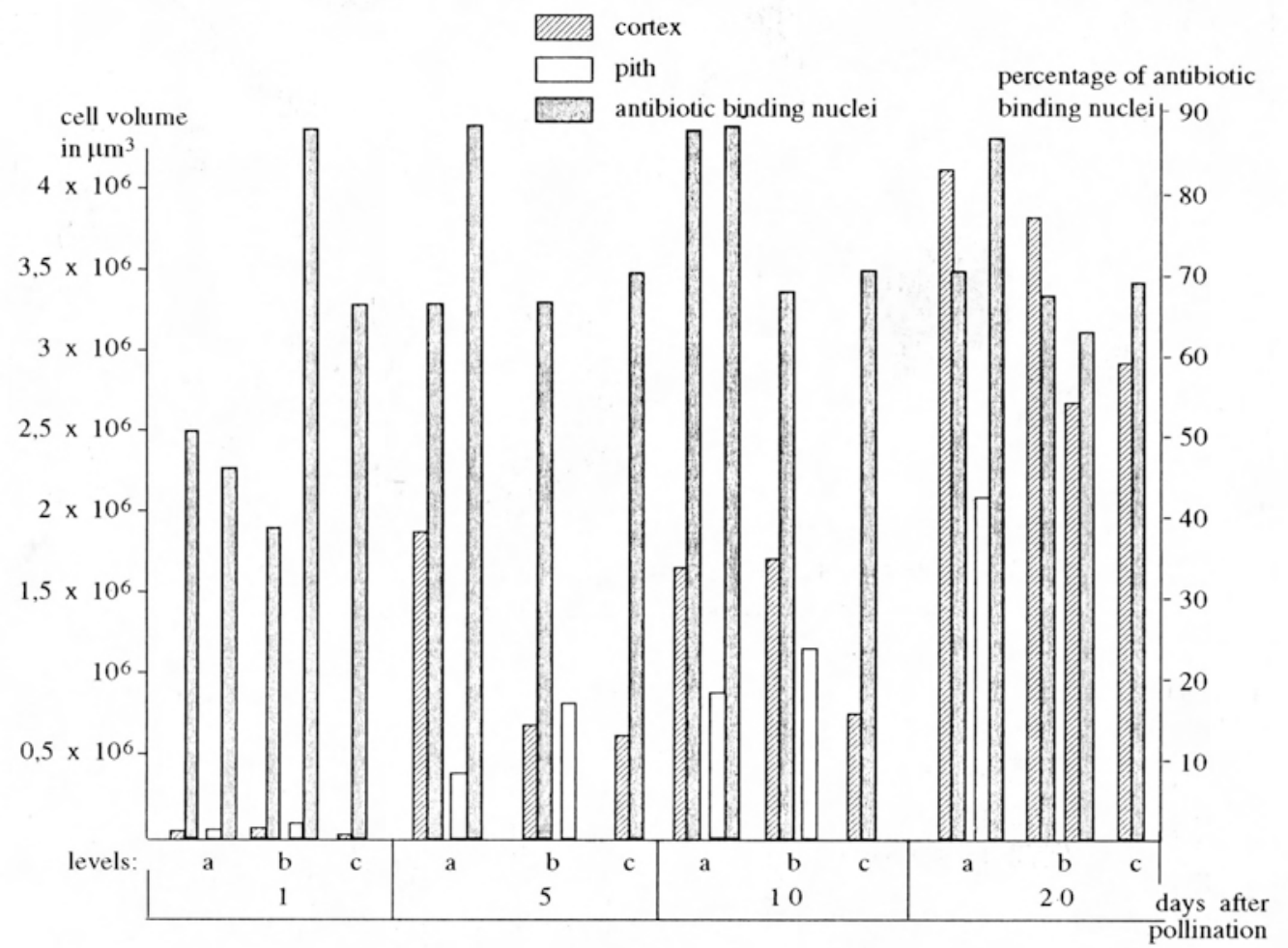

Fig. 10. The relationship between the cell volume and number of nuclei binding ${ }^{3} \mathrm{H}-\mathrm{AMD}$

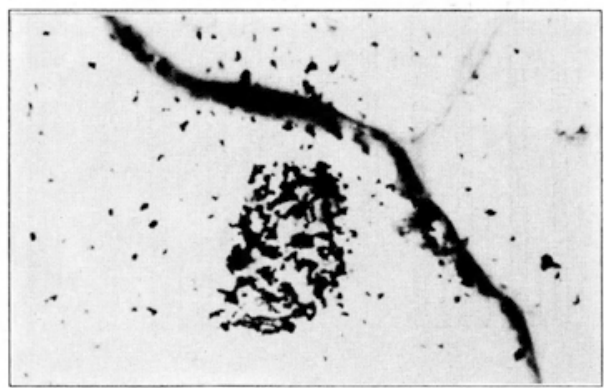

Fig. 11. A nucleus in an ${ }^{3} \mathrm{H}-\mathrm{AMD}$ autoradiogram $x 1200$ (the cortex of the receptacle 20 days a. p., level a) 
The nucleoli were not found to be labeled with ${ }^{3} \mathrm{H}$-AMD on the autoradiograms. The relationship between the number of nuclei labeled with ${ }^{3} \mathrm{H}$-thymidine and the number of nuclei binding ${ }^{3} \mathrm{H}-\mathrm{AMD}$ is presented on Fig. 12. It can be seen from these results that up to and including 10 days a.p., the number of nuclei binding ${ }^{3} \mathrm{H}$-AMD exceeded the number of nuclei labled with ${ }^{3} \mathrm{H}$-thymidine. In the fruit 20 days a.p., however, with the exception of the pith in the lower part, the number of nuclei binding ${ }^{3} \mathrm{H}$-AMD was equal to or slighlty greater than the number of nuclei incorporating ${ }^{3} \mathrm{H}$-thymidine (Fig. 12).

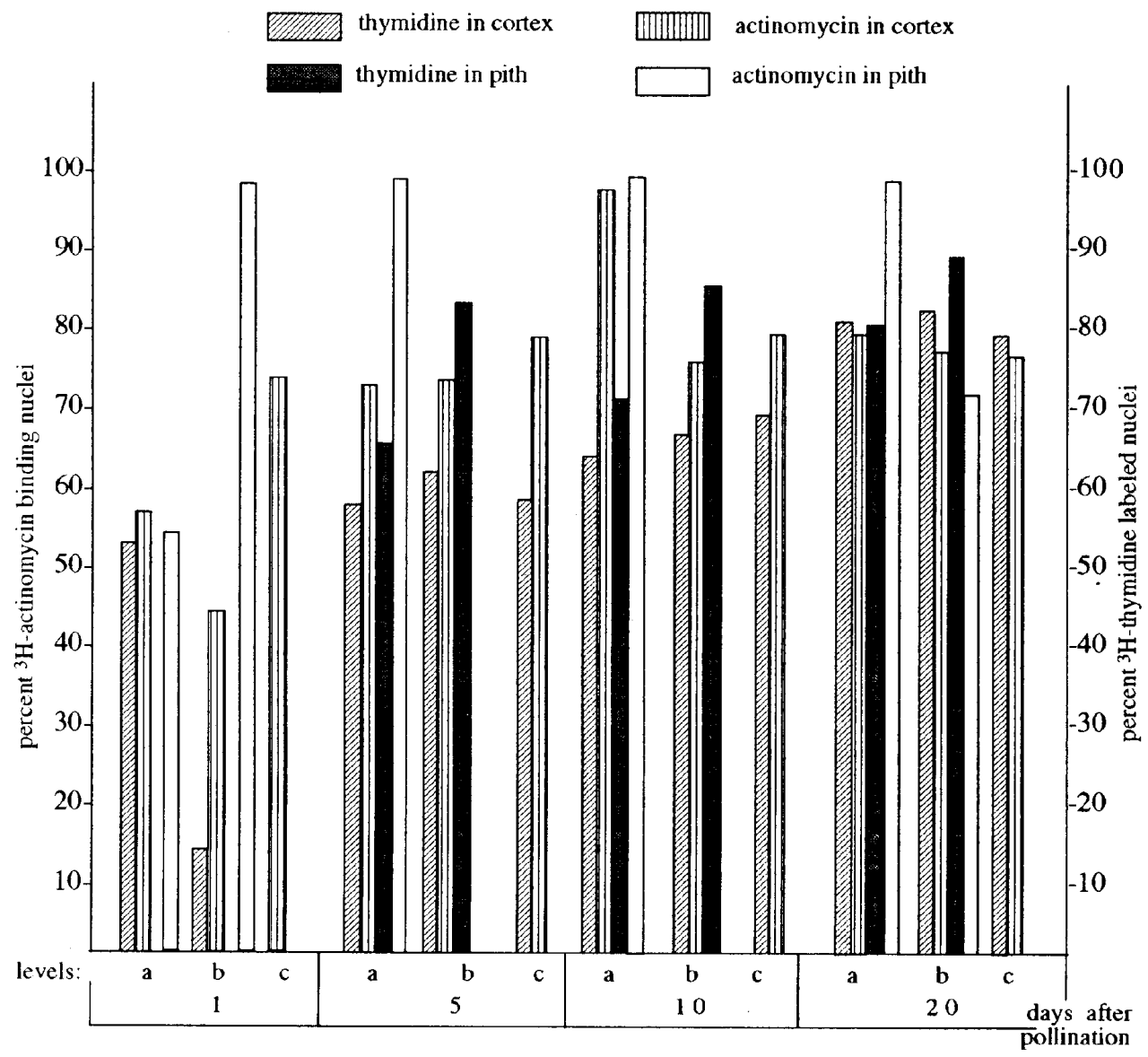

Fig. 12. The relationship between the ${ }^{3} \mathrm{H}$-thymidine and ${ }^{3} \mathrm{H}$-actinomycin labeled nuclei 


\section{DISCUSSION}

The early stages of the development of the receptacle have been included in this study. The most of advanced stage examined in these experiments, 20 days a.p., called by $\mathrm{N}$ e a 1 (1965 a) the green - white stage, is the start of ripening.

The presented reults dealing with the growth dynamics of the strawberry fruits cells in its successive developmental stages point to the increase in cell volume. A significant increase in cell number, proceding until almost the last stage (compare S z y m a ń s k i, 1982), was also observed. S i n n o t t (1939) in studies on the development of cucurbites fruit from the stage of the ovule to maturity, emphasizes the first rate importance of cell division, but also points to the increase in cell dimensions.

Cell divisions usually stop when a certain threshold cell size and fruit age are reached (H o u h t a l i n g, 1935; T u k e y, 1974). The increase in tissue dimensions then takes place through increase in cell size. In the tomato, Lacopersicon esculentum Mill., the cell number is determined very early in the process of fruit development, while in Lycopersicon pimpinellifolicum (Juslem) Mill. (a wild species), cell divisions continue until the fruit is ripe, similary as in the avocado fruit ( $\mathrm{C} \mathrm{o}$ o $\mathrm{m} \mathrm{b}$ e, 1976).

$\mathrm{H}$ a $\mathrm{V}$ is (1943) pointed to the fact that in strawberry fruit, the cortex grows faster then the fruit as a whole (120-125\%). This growth is slower at first, faster in the later stages. The pith, on the other hand, grows more slowly than the rest of the fruit $(73-79 \%)$. The cross-sections used by the mentioned author were taken only from the middle part of the receptacle, which in this report is denoted as the middle level or part. In this area the predominance of the cortex over the pith is, in fact, visible, as well as over the fruit as a whole. In the apical part, the pith is not set apart.

The incorporation of ${ }^{3} \mathbf{H}$-thymidine is commonly accepted as an indicator of DNA replication (O l s z e w s k a and O s i e c k a, 1982) and also makes it possible to demonstrate the relationship between DNA replication and cell growth (C a pe s i u s et al., 1972, 1981).

Comparing the average number of cells in the particular stages and levels (parts) in assotiation with ${ }^{3} \mathrm{H}$-thymidine incorporation makes it possible to follow the process of endomitosis. Between some of the stages the number of cells did not change much in comparison with the number of nuclei synthesizing DNA, which allows it to be concluded that endomitotic DNA replication was taking place in a great majority of the nuclei. 
This applies to the following stages: 5, 10 and 15 days a.p. in the lower part of the pith cells, 15 and 20 days a.p. in the lower part of the pith cells and 15 and 20 days a.p. in the middle part of the cortex cells, 5, 1015 and 20 days a.p. in the middle part of the pith cells, as well as 5 and 10 days a.p. in the apical part of the cortex cells.

The incorporation of ${ }^{3} \mathrm{H}$-thymidine was especially high in the oldest stage (20 days) and distinctly correlated with the large volumes of the nucleus and cortex and pith cells, which along with the lack of cell divisions (no new cells are formed) points to the endomitotic replication of DNA. This process was acompanied not only by the increase in nuclear volume, but by that of the nucleoli as well. However, in the apical part starting from day 5 a.p., the volume of nucleoli no longer increased in spite of the fact that endomitotic DNA replication continued in the nuclei. The results presented by C z a p s k i (1976) which indicated that the histone content of strawberry fruit increases are in agreement with the conclusions on the occurrence of endomitotic DNA replication in this object. In the oldest stage in which there were no mitoses, the increase in cell volume could only be associated with endomitotic polyploidization.

$\mathrm{N}$ a g 1 (1978) emphasizes the importance of the nucleotypic effect, taht is, the relationship between the DNA content, dry weight of cells, duration of the cell cycle, duration of meiosis and the size of nuclei and cells. N a g 1 (1978) also discussed the problem if endoploidization is the cause or result of cell differentiation. In light of new views on growth ( $\mathrm{T} \mathrm{a}$ w a $\mathrm{v} \mathrm{a}, 1986)$ this problem is not of any specific importance. C a p e s i u s et al. $(1972,1974,1974 \mathrm{a}, 1981)$ are of the opinion that the elongation of cells in the hypocotyl of white mustard is dependent on the previous replication of DNA. Nuclear polyploidy is a specific stage in the control system preceding an increase an cell volume.

$\mathrm{N}$ a $\mathrm{g} l$ (1974) draws attention to the fact that polyploid cells are usually larger than diploid cells. He suggests, however, that the growth of the cell is not the result of the increase in nuclear DNA content, but the opposite, that just the increase in cell size can induce DNA synthesis. M i l l e r d and W h i l f i e l d (1973) found that the DNA content and increase in dry weight of broad bean cotyledons are significantly correlated with endocycles.

The intensity of ${ }^{3} \mathrm{H}$-AMD binding, in light of data from literature, is an indicator of the template activity of DNA. The method of incubating previously fixed material in a solution of $3 \mathrm{H}$-AMD used in this study makes it possible to trace the relationship between endomitotic replication of DNA and the binding of 3 H-AMD. 
FAA was used to fix the material because a fixative shich does not remove histones ( $\mathrm{S} \mathrm{i} \mathrm{v} \mathrm{a} \mathrm{k}$ and $\mathrm{W}$ o $\mathrm{l} \mathrm{m} \mathrm{a} \mathrm{n}, 1974$ ), is best in such a situation. Comparison of the number of nuclei incorporating ${ }^{3} \mathrm{H}$-thymidine with the number of nuclei binding ${ }^{3} \mathrm{H}$-AMD indicates that the intensity of these two processes in the cortex of the studied material was similar. These results point to the possibility that the biological role of endomitosis is the multiplication of the matrix (DNA), which may increase the metabolic potential of the cell and play a part in its more rapid growth. It is puzzling that the cells in the pith in the 5 and 10 days a.p. stages in the middle part were not labeled.

It is worth emphasizing that the mean number of nuclei biding ${ }^{3} \mathrm{H}-\mathrm{AMD}$ in the cells of the cortex in all of the studied parts was highest 10 days a.p. and decreased somewhat 20 days a.p., while the number of nuclei incorporating ${ }^{3} \mathrm{H}$-thymidine was constantly increasing. These results point to the conclusion that the mere multiplication of the DNA content through endomitosis is not a sufficient factor for a corresponding increase in genome activity. $\mathrm{O} 1 \mathrm{~s} \mathrm{z} \mathrm{e} \mathrm{w} \mathrm{s} \mathrm{k} \mathrm{a}$ (1976) found a similar fact in the process of the differentiation of the primary root cortex of Cucurbita pepo L. It therefore should be concluded that both in the zone of differentiated cells in the roots of the pumpkin as well as in the receptacle in the 20 days a.p. stage, in spite of the multiplication of the amount of the matrix DNA through endomitotic replication, its activity is reduced.

In conclusion it should be stated that during the development of the strawberry receptacle, specjally in the last stages (0-20 days a.p.), the volume of cells increases very intensely and is accompanied by endoreplication of nuclear DNA (visible especially 20 days a.p. when there are no more mitoses). The increased DNA content is correlated with its increased template activity, measured by binding ${ }^{3} \mathrm{H}$-AMD.

\section{Acknowledgment}

The author would like to express his gratitude to prof. Mana J. Olszewska for her valavable advice during the preparation of this paper.

\section{REFERENCFS}

B e rl ow it z L., P a llot a D., S i ble y C. H., 1969. Chromatin and histones, binding of tritiated AMD to heterochromatin in mealy bugs. Science 164: 1527-1529.

B i I e c k a A., 1974. Wplyw hydroksymocznika na syntezę kwasów nukleinowych i bialek w tkankach prawidłowych i tumorowych Nicotiana tabacum in vitro. Praca dokt. U.Ł., Łódź.

Capesius J., B opp M.. CI a u s s W., 1972. Die lag. Phase bej der FUDR--Wirkung auf DNA Synthese 
and Streckungswachstum bei Sinapis alba. Planta (Berl.) 103: 65-73.

Capesius J., Stohr M., 1974. Endopolyploidisierung wahrend des Streckungswachstums der Hypokotyle von Sinapis alba. Protoplasma 82, 147-153.

Capesius J., B opp M., 1974. Nachweis der DNA - Synthese in Hypocotylen und Cotyledonen gehemmter und nicht gehemmter Keimlinge von Sinapis alba. Planta (Berl.) 118: 171-181.

Capesius-Es sigman n J., Wi l h e $1 \mathrm{~m}$ W., B op p M., 1981. Der Einfluß Van Chlorcholin-chlorid (CCC) auf Zellwachstum und Ploidiegrad bei Phaseolus vulgaris Z. Pflanzenphysiol. Bd. 104, 353-362.

Co o m be B. G., 1976. The development of fleshy fruit. Ann, Rev. Plant Physiol. 27: 207-208.

C z a p s k i J., 1976. Badania nad białkami owoców truskawki. Prace Inst. Sad. Ser. C (1-2): 189 - 190.

G r a i n g e r J., 1956. The economic effects of crop disease. The West of Scotland Agricultural College Research Bulletin 16: 21-23.

$\mathrm{H}$ a $\mathrm{v}$ is A. L., 1943. A developmental analysis of the strawberry fruit. Amer. Jour. Bot. 30: 311.314.

H o u g h a 1 in g H. B., 1935. A developmental analysis of size and shape in tomato fruits. Bull. Torrey Club 62: 243-252.

J e n e n W. A., 1962. Botanical histochemistry, Freeman C.O., San Francisco.

Ko n o n o w i cz A., Kura n H., O l s ze w s k a M. J., 1976. Cytochemical and ultrastructural study of changes in the nucleus and nucleolus during cell differentiation in the root cortex of Hemanhus kathurine.

Folia Histochem. Cytochem. 14: 151-164.

Mac Arth u r M., We t more R. H., 1941. Developmental studies of the apple fruit in the varieties Mc Intosh Red and Wagner. II. An analysis of development. Canad. Jour. Res. C. 19: 371-382.

Mille r d A., Wh if feld R. R., 1973. DNA and RNA synthesis during the expansion phase of cotyledon development in Vicia faba L. Plant Physiol. 51 : 1005-1010.

$\mathrm{N}$ a $g$ l W., 1978. Endopolyploidy and polyteny in differentiation and evelution. North-Holland Publ. Comp., Amsterdam.

$\mathrm{Ne}$ a 1 G. E., 1965. Changes occurring in the walls of strawberries during ripening. J.Sci. Fd. Agric. 16: 604-61 1. O Is zew s k a M., 1976. Autoradiographic and ultrastructural study of Cucurbita pepo roots cells during their growth and differentiation. Histochemistry 49: 145-175.

O Is ze ws ka H. B., Y o n g J. O.. 1942. Gross morphology and histology of developing fruit of the apple. Bot. Gaz. 104: 1-24.

O ls ze e s k a M. J., O s ie ck a R., 1982. The relationship between 2C DNA content, life cycle type, systematic position, and the level of DNA endoreplication in nuclei of parenchyma cells during growth and differentiation of roots in some Monocotyledonous species. Biochem. Physiol. Pflanzen 177: 319-336.

Pe a r s o n G. G., T i In m i s J. N., I n g le I., 1974. The differential replication of DNA during plant development. Chromosoma (Berl.) 45: 281-294.

S i n n o t t E. W., 1939. A developmental analysis of the relation between cell size and fruit size in cucurbiles. Amer. Jour. Bot. 26: 179-189.

S i v a $\mathrm{k}$ A., V o $1 \mathrm{~m}$ a $\mathrm{n}$ S. R., 1974. Chromosomal protein in fixed metaphase cells. Histochemistry 42: 345-349.

S z y m a ń s k i J., 1982. Anatomical investigations of the strawberry (Fragaria grandiflora Ehrh.) receptacle in the initial stages of development. Acta Agrobot. 34: 195-207.

Trew a v A.. 1986. Understanding the control of plant development and the role of growth substance. Aust. J. Plant Physiol. 13: 447-457.

Tuk e y L. D., 1974. Some relations in the growth and development of apple fruite. Proc. of the XIX Inter. IIort. Congress, III, 35-45.

Tuke y H. B.. Y o u g J. O., 1942. Gross morphology and histology of developing fruit of the apple. Bot. Gaz. 104: 1-24. 


\section{Badania cytomorfologiczne i autoradiograficzne dna kwiatowego truskawki (Fragaria grandiflora Ehrh.) w początkowych stadiach rozwoju.}

\section{Streszczenie}

W korze i w rdzeniu owoców truskawki odmiany Talizman, objętośc komórek wzrasta stopniowo aż do dojrzcwania, szczególnie w korze. Objętość jądra zwiększa się. Jądra w rdzeniu są mniejsze niż w korze. Objętość jałderka zwiększa się znacznie między 1 a 5 dniem po zapyleniu, a poźniej pozostaje bez zmian. Pod koniec wrrostu zwięk szają objętość jąderka w komórkach kory i rdzenia w dolnej i środkowej części owocu. Podczas rozwoju dna kwiatowego następuje endomitotyczna poliploidyzacja odpowiedzialna za wzrost owocu. Intensywność wiązania ${ }^{3} \mathrm{H}$-aktynomycyny osiąga najwyższy poziom w stadiach najstarszych. Jest ono dowodem nagromadzenia się aktywnego DNA w procesie mitozy. Nasycenie tym antybiotykiem następowało we wczesnych stadiach rozwojowych owocu. Nie zauważono zależności między objętością komórek a liczbą jąder wiążących ${ }^{3}$ H aktynomycynę. 